\author{
Andrijana Broćić* \\ University of Belgrade \\ Faculty of Philology \\ Belgrade, Serbia
}

\title{
PRIDE AS A METAPHORICAL TREASURE: THE CONCEPTUALIZATION OF PRIDE AND SELF-RESPECT IN ENGLISH AND SERBIAN VIA 'THE POSSESSION OF A PRECIOUS OBJECT' SCENARIO
}

\begin{abstract}
This paper explores the conceptualization of a subset of emotion concepts related to positive self-evaluation - pride, self-respect, self-esteem and dignity in English and ponos, samopoštovanje and dostojanstvo in Serbian - via a metaphorical scenario referred to in the paper as "the possession of a precious object scenario". The analysis was performed within the theoretical framework of Conceptual Metaphor Theory and is based on the data obtained from general corpora. The results indicate a high level of productivity of the metaphorical scenario in the structure of PRIDE and SELF-RESPECT in both languages, as well as the salience of the elements of 'destruction', 'theft/loss' and 'defence/preservation' within the scenario. The analysis also sheds light on some of the potentially manipulative aspects of the structuring of collective pride, dignity and honour via this scenario in Serbian public discourse, pointing to a need for further research in that direction.
\end{abstract}

Key words: pride, self-respect, dignity, conceptual metaphor, precious possession, English, Serbian

E-mail address: andrijana.brocic@gmail.com; andrijana.brocic@fil.bg.ac.rs 


\section{Introduction}

The cross-linguistic differences and similarities in the metaphoric conceptualization of emotions have been the subject of a number of cognitive linguistic studies (e.g. Kövecses 2005; Kosanović 2009, 2016; Dziwirek \& Lewandowska-Tomaszczyk 2010; Ogarkova \& Soriano 2014a, 2014b). Following that line of research, this paper deals with the metaphoric conceptualization of a subset of emotion concepts related to positive self-evaluation - pride, self-respect, selfesteem and dignity in English and ponos 'pride', samopoštovanje 'self-respect' and dostojanstvo 'dignity' in Serbian - by means of a metaphorical scenario referred to in the paper as "the possession of a precious object scenario". Based on the linguistic analysis of a corpus of examples obtained from representative corpora, the paper sets out to explore the similarities and differences in the conceptualization of pride and self-respect via the above scenario in English and Serbian at conceptual, linguistic and cultural levels ${ }^{1}$.

\section{Theoretical and methodological background}

One of the central tenets of Conceptual Metaphor Theory (henceforth CMT; Lakoff \& Johnson 2003[1980]), and more generally, cognitive linguistics, is that metaphor is an indispensable cognitive mechanism responsiblefor understanding one conceptual domain (target domain) in terms of another (source domain); the target domain is usually (but not necessarily) abstract, whereas the source domain is usually concrete and more clearly delineated in our everyday experience (Lakoff \& Johnson 2003[1980])2. Conceptual metaphors therefore only indirectly emerge as metaphorical linguistic expressions - in the domain of emotions, for example, 'Shame burned within her' would be regarded as a linguistic instance of the conceptual metaphor SHAME IS FIRE.

1 This paper is based on a much larger study into the conceptualization of self-conscious emotions in English and Serbian (Broćić 2018a).

2 For a detailed account of this conceptual phenomenon see e.g. Klikovac (2004), Kövecses (2010[2002]). 
Within cognitive linguistic research, the conceptual representation of emotions has received considerable attention, especially regarding metaphors structuring emotion concepts, and the issues such as the experiential grounding of emotion metaphors, their potential universality and variation across languages and cultures, or the question of whether there are any emotion-specific metaphors have been discussed in great detail (c.f. Lakoff 1987; Kövecses 1986, 1998, 2000, 2005, 2008a, 2008b, 2010[2002], 2014; Grady 1997; Lakoff \& Johnson 1999). Kövecses (2000, 2008a, 2008b), for instance, argues that emotions are conceptually represented as cognitive or rather cognitive-cultural models, which are in turn composed of conceptual metaphors, metonymies and related concepts. The most prototypical cognitive model underlying the concept of EMOTION can be schematically characterized as a five-stage scenario consisting of the following elements: cause (of emotion) - emotion - controlling emotion - loss of control - (behavioural) response (Kövecses 2000: 58). More recently, Kövecses (2014) has elaborated on "the emotion-as-cognitive-cultural-model idea" (p. 23) by drawing on the notion of 'domain matrix', originally proposed by Langacker (1987). Succinctly put, it is suggested that the concept of EMOTION evokes a vast array of additional concepts, constituting a domain matrix: for instance, it evokes the notions of SOCIETY, SOCIAL RELATIONS, SOCIAL NORMS, as well as the notions of RIGHT or WRONG, APPROPRIATENESS OF RESPONSE, APPROPRIATE MEASURE OF FEELING etc. since emotions commonly arise in social situations and derive from moral ideas. Importantly, the emotion domain matrix that is activated depends on the context in which it is used (ibid. pp. 23-24).

Given that every conceptual metaphor has a meaning or semantic focus (Kövecses 2010[2002]; Soriano 2015), i.e. it highlights certain aspects of the target domain while simultaneously hiding others (Lakoff \& Johnson 2003[1980]), metaphor analysis is helpful in discovering those aspects that are particularly salient in the structure of specific emotion concepts. For instance, the conceptualization of emotions in terms of HEAT and FIRE accentuates their intensity as well as their potentially destructive aspects (see Kövecses 2000; Klikovac 2006 [2000]; Broćić 2018a, 2018b), whereas the domains of WARMTH and LIGHT impart a highly positive evaluation to a particular emotion, e.g. HAPPINESS IS LIGHT/WARMTH (Kövecses 2008a; Kosanović 2009) and 
PRIDE IS WARMTH/LIGHT (Broćić 2012, 2018a, 2018b) in English and Serbian. In addition, some of the major semantic foci in the domain of emotions include the following: existence, positive/negative evaluation, harm, passivity, (an attempt at) control (Kövecses 2000), self-regulation, the intrinsic controllability and degree of expressivity of a particular emotion (Ogarkova \& Soriano 2014b).

In this respect, the study of emotion metaphors has also proved to be a useful tool for uncovering prevalent folk (as opposed to expert) theories of emotions, or even ideologies lying at the heart of such folk theories. Goatly (2007) thus claims that the folk view of love, as enshrined in the dominant metaphors for love in English, namely, EMOTION IS FORCE, WEATHER, MOVEMENT, A CURRENT IN A LIQUID, portrays the experiencer as essentially passive in relation to it, or as Goatly puts it, it is "a sickness caught involuntarily, an irresistible gravitational force, a "falling" in love" (ibid. p. 199). On the other hand, Soriano (2015) and Ogarkova and Soriano (2018) have emphasized the relevance of CMT-based studies of emotion concepts for the disciplines such as cross-cultural emotion psychology, or, more generally, the affective sciences. For instance, metaphor analysis can reveal aspects of emotion particularly salient for 'laypeople', but potentially neglected in expert theories - as suggested by Soriano $(2013,2015)$, the prominence of the metaphors ANGER IS INSANITY and ANGER IS ILLNESS shows that both irrational behaviour and the damage anger can cause to the experiencer form an important part of our folk representation of the emotion; these aspects are, however, frequently neglected in the descriptions advanced by experts theories, which, by and large, focus on the overall utility of emotions as adaptive mechanisms and anger-induced aggressive behaviour.

In recent research, practitioners of corpus linguistics have focused on the different types of contributions that data-driven corpus-based approaches have made to metaphor theory and analysis, claiming that reliance on large collections of authentic texts can render metaphor analysis more accurate (e.g. Deignan 2005, 2006, 2008; Stefanowitsch 2006a, 2006b; Semino 2017; Ogarkova \& Soriano 2014a). In the domain of emotions, Stefanowitsch (2006b) and Ogarkova and Soriano (2014a, 2014b), for instance, make use of large corpora to establish a full inventory of conceptual metaphors structuring a particular emotion concept and discover whether 
those metaphors are frequent in a statistically significant way (e.g. Stefanowitsch (2006b) found that ANGER IS A HEATED LIQUID figures prominently in the structure of ANGER). On the other hand, Deignan's (2008) and Broćićs (2018a, 2018b) corpus-based research into heat and fire metaphors of anger and pride suggests that those metaphors are predominantly associated with the collective anger/pride and behaviour of people as a group rather than as individuals. In addition, as shown by Broćić (2018a, 2018b), close attention must be paid to both connotative and contextual meanings of metaphorical expressions in order to more accurately determine the utilized elements of the identified source domains, those aspects of the target domains highlighted by the pertinent conceptual metaphors, as well their underlying experiential bases. To illustrate, Broćićs (2018b) fine-grained analysis of the metaphorical expressions instantiating PRIDE IS HEAT and SHAME IS HEAT demonstrated that these metaphors differ with respect to their meaning foci and experiential bases, i.e. "PRIDE IS HEAT focuses on the existence and intensity of pride in both English and Serbian, as well as its potential to incite the experiencer to violence in Serbian; SHAME IS HEAT, on the other hand, foregrounds the intensity and severity of shame, and the magnitude of its effects from the perspective of the experiencer" (p. 61).

\section{Reification and "the possession of a precious object scenario"}

The use of abstract nouns to refer to emotional experiences reflects the conceptual process of objectification, i.e. reification (Langacker 1991), or a specific type of metaphorical shift known as ontological metaphor (Lakoff \& Johnson 2003[1980]) whereby we view relational concepts as abstract things. For instance, the relation 'be happy' is construed as a thing when we speak of 'happiness'. According to Lakoff and Johnson (2003[1980]: 25-32), objectifying our experiences through ontological metaphors, that is, understanding them in terms of objects and substances, allows us to "refer to them, categorize them, group them, and quantify them and by this means, reason about them" (p. 25). The objectification of emotions through ontological metaphors thus enables us to identify and define the private sensation of emotion and ultimately motivates 
their more specific conceptualization as objects that may be desirable, undesirable, possessed, acquired, given, lost, preserved, thereby allowing us to capture different aspects of emotional experience. For instance, pride and self-respect being defined as positive emotional states, it is natural that, alongside happiness and other positive emotional experiences, they should be understood as VALUABLE OBJECTS. The source domain POSSESSION OF AN OBJECT is, for instance, used to conceptualize the existence of emotion, or as explicitly argued by Kövecses (2000), the metaphor EXISTENCE OF EMOTION IS POSSESSION OF AN ОвJЕст is one of the three major metaphors that focus on the existence of emotion and apply to all emotion concepts, the other two being EXISTENCE OF EMOTION IS PRESENCE HERE and EXISTENCE OF EMOTION IS BEING IN A BOUNDED SPACE. These source domains are by no means restricted to emotion concepts - EMOTION IS A POSSESSED OBJECT is an instantiation of the higher-level ATTRIBUTES ARE POSSESSED OBJECTS metaphor, which, in combination with the Changes Are Movements of Possessions (acquisitions and losses) and Causation Is Transfer of Possessions (giving and taking) submappings, forms part of the Object EventStructure Metaphor (Lakoff 1993; Lakoff \& Johnson 1999).

The main aim of this paper is to explore the role of the VALUABLE POSSESSION/PRECIOUS OBJECT SOurce domain - or, more specifically, the metaphors which jointly constitute "the possession of a precious object scenario" - in the conceptualization of pride and self-respect in English and Serbian based on corpora examples. The term "the possession of a precious object scenario" will be used throughout the paper to refer in particular to the following submappings: the elements of 'acquiring', 'possessing', 'losing', 'stealing', 'destroying', 'preserving/defending' and 'returning' a precious object.

\section{Data and method}

The English data for the analysis were excerpted from the British National Corpus (henceforth BNC), whereas the Serbian examples were gathered from the electronic Korpus savremenog srpskog jezika (henceforth KSSJ, [Corpus of the Contemporary Serbian Language]). Both corpora are relatively evenly balanced across different genres of written languages and are approximately of equal size (the 
BNC contains 100 million words, whereas the KSSJ currently contains 113 million words), thus providing an adequate basis for a comparative study of the metaphors in the two languages and for some generalization to be made.

The linguistic examples contain the target domain lexis - for the concept PRIDE, the nouns pride in English and ponos in Serbian, and for SELF-RESPECT, the nouns self-esteem, self-respect, dignity in English, and samopoštovanje, dostojanstvo in Serbian.

The procedure and analysis involved the following steps: first, a random (nth-basis) sample of 1000 examples for each lexical item under examination was retrieved from the corpora, and in case there were fewer than 1000 occurrences, all the citations were extracted (for instance, 738 for dignity, self-esteem - 421, self-respect - 190, and samopoštovanje-266). Next, upon identification of metaphorical expressions, the underlying conceptual mappings were established on the basis of the meanings of the words which collocate with the noun lexemes designating the abstract concepts of pride and selfrespect, for instance, pride reawakens, ponos se budi > PRIDE IS A LIVING BEING/AN ANIMATE ENTITY; the identified metaphors were subsequently grouped following the basic classification of metaphors into those with the source domains of AN OBJECT, LIVING BEING, SUBSTANCE, LOCATION and CONTAINER (see Broćić 2018a).

The quantitative analysis showed the realizations of the genericlevel овјЕст metaphor to be prominent in both corpora, accounting for over $50 \%$ of all the identified metaphors structuring the concepts under consideration. In particular, the metaphors that can be subsumed under the PRECIOUS POSSESSION SCENARIO provide the bulk of all the realizations of the овлест metaphor, especially in the case of concepts more closely related to self-respect. It can thus be concluded, based on the quantitative data alone, that this metaphorical scenario is particularly salient in the structure of the concepts under discussion. The full quantitative data for both the high-level овјест metaphor and the more specific POSSESSION OF A PRECIOUS OBJECT SCENARIO are given in Table 1: 


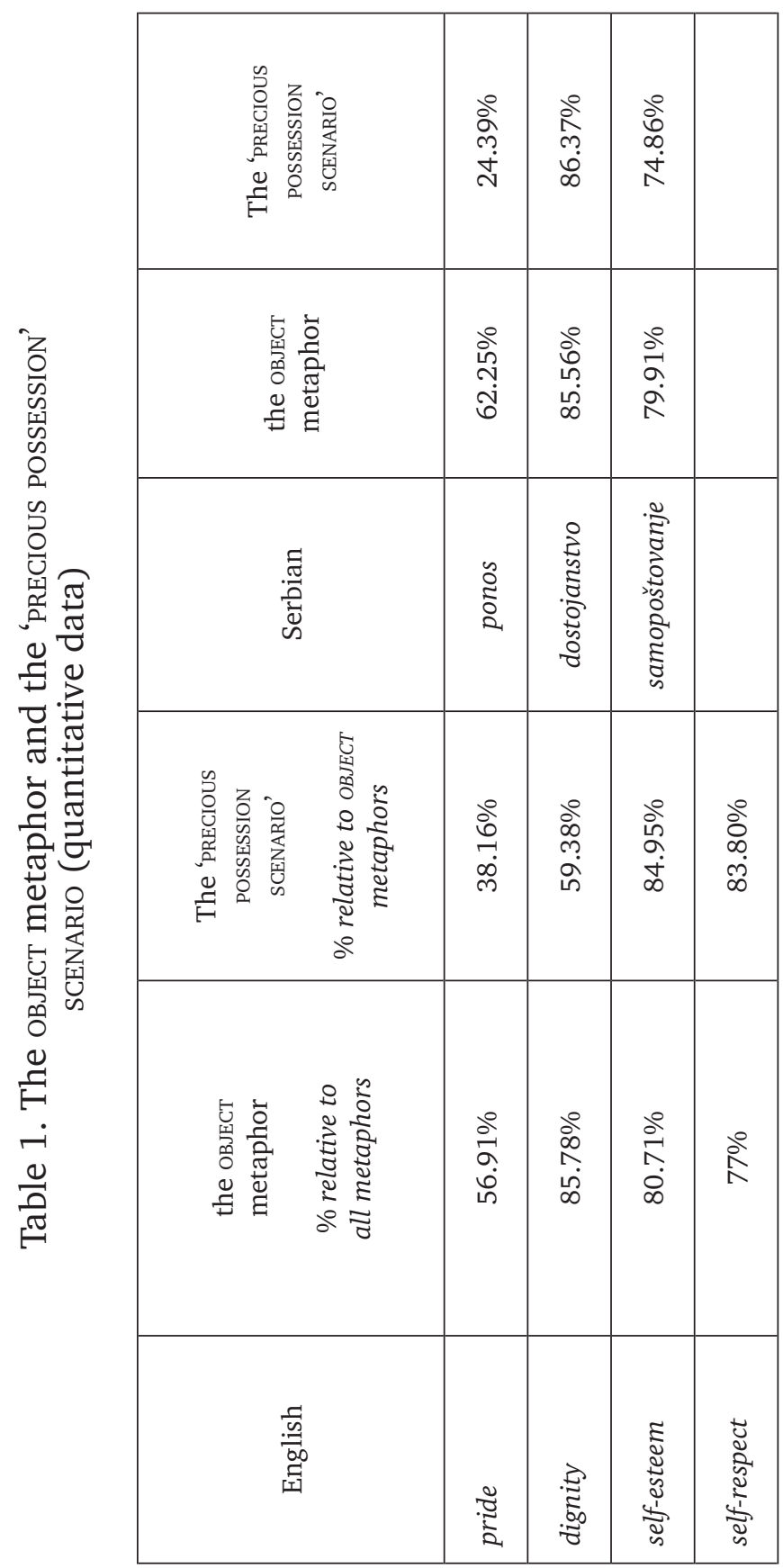




\section{Results and analysis}

\subsection{The elements of 'acquiring' and 'possessing' a (valuable/precious) object}

The examples from our data confirm that FEELING PRIDE/SELF-RESPECT can in both languages be conceptualized as BEING IN POSSESSION OF PRIDE/SELF-RESPECT-OBJECT, whereas, in line with the Object EventStructure Metaphor (Lakoff 1993; Lakoff \& Johnson 1999), BEGINNING TO FEEL PRIDE/SELF-RESPECT and AWAKENING PRIDE/SELF-RESPECT IN SOMEBODY are construed as ACQUIRING and GIVING PRIDE/SELF-RESPECT-OBJECT (TO SOMEBODY) respectively:

$\mathrm{E}$ :

(1) He gave me pride in myself and made me feel wanted ${ }^{3}$.

(2) Men and women who brought a renewed sense of pride and selfrespect to our country.

(3) Director Roland Joffe tries to bring home the pride and dignity of people existing in the meanest of mean streets.

(4) We need to give children dignity and self-respect

(5) Through Highlander's programs, many people have been encouraged to find beauty and pride in their own ways, to speak their own language without humiliation

(6) It is inevitable that my own hard-won sense of propriety or dignity should tempt me into being the scourge of other, more self-indulgent beings.

(7) With my new-found self-respect I may decide to refuse any longer to be called by that ridiculous name.

(8) Although I am down, I still have my pride and dignity.

3 Representative English and Serbian examples were selected to illustrate the pertinent conceptual mappings. The Serbian examples (or parts thereof) are followed by wordfor-word translation into English. 
(9) They forced me to leave. But I left of my own free will. I wouldn't give them the satisfaction. I resigned. I have my pride, you know. They can't kick me around.

S:

(10) Svome bratu je ostavio vojnički ponos

'He left his brother military pride'

(11) Pacijentima moramo pružiti osećaj sigurnosti i ljudskog dostojanstva tokom lečenja

'We must give our patients a sense of security and human dignity during treatment'

(12) mnogi od njih imaju zadovoljstvo od tog svog znanja, koje je ravno čitavoj nauci, stiču na taj način samopoštovanje

'many of them derive satisfaction from that knowledge.... acquiring self-respect in the process'

(13) Tito, Naser i Nehru, u najžešćoj konfrontaciji velesila, okupili su male, nesvrstane i nerazvijene zemlje i dali im po prvi put osećaj samopoštovanja i dostojanstva.

'Tito, Nasser and Nehru.....brought together small, non-aligned and underdeveloped countries, giving them for the first time a sense of self-respect and dignity'

(14) Nekada je ovaj narod imao ponos

'This nation used to have pride'

(15) Ali, novi predsednik Venecuele se zasad ne osvrće mnogo na pritiske Bele kuće. ,,Mi imamo svoj ponos. Venecuela je suverena zemlja koja donosi odluke u skladu sa svojim interesima". 'But the new president of Venezuela doesn't pay much attention to the pressures of the White House. „We have our pride. Venezuela is a sovereign country and makes decisions in accordance with its own interests'.

On the basis of the above examples, it can be observed that the metaphors EXISTENCE OF PRIDE IS POSSESSION OF PRIDE-OBJECT and AWAKENING PRIDE IN SOMEBODY IS GIVING SOMEBODY PRIDE-OBJECT are more often than not constitutive components of the form of pride that can 
be characterized as 'a sense of self-respect', rather than 'pride as an immediate emotional reaction to something'. The frequent cooccurence of the lexemes pride/ponos and dignity/dostojanstvo, selfrespect/samopoštovanje in the same context further corroborates this conclusion ${ }^{4}$.

Also, the wider context in which the examples are embedded further indicates that the PRIDE-AS-THE POSSESSED OBJECT metaphor can, apart from the existence of pride, additionally highlight that the emotional state of pride gives the experiencer the strength to fight for him/herself, i.e. this metaphors underlines that 'having pride'entails not allowing others 'to kick us around', as explicitly stated in examples (9) and (15).

What is also observable is that the experiencer is often portrayed as the passive recipient of pride/dignity-object. Namely, while the subject can through personal efforts acquire, win or earn pride/ dignity-valuable object, in the vast majority of the examples this object is explicitly given to the experiencer. Moreover, it is often emphasized that it is incumbent on somebody else to provide the experiencer with the valuable object, for instance, parents should give it to children. This can be taken as evidence that according to the folk view of pride and self-respect, as manifest in English and Serbian, whether we will start feeling pride and self-respect frequently depends on other people.

It is obvious that in the above examples pride/self-respect is characterized, albeit implicitly, as a sought-after or valuable object. There are a number of examples, however, in which pride/self-respect is explicitly construed as a VALUABLE Or PRECIOUS POSSESSION; some of the examples also point to further specific-level metaphors within the generic-level PRIDE/SELF-RESPECT IS A VALUABLE POSSESSION metaphor:

4 Broćićs (2018a: 148-161) corpus-based analysis of the metaphors structuring pride has identified four cognitive models associated with the concept of pride in both English and Serbian: 1) PRIDE/PONOS 1: 'an immediate emotional reaction to something' and 'enduring emotional response to something'; 2) PRIDE/PONOS 2: 'self-respect'; 3) PRIDE/PONOS 3: '(stubborn) preoccupation with personal worth' and 4) PRIDE/PONOS 4: 'excessive pride and a sense of superiority'. As argued by Kövecses (1986), 'balanced pride as immediate response' - which is the equivalent of the above 'PRIDE/PONOS 1' - is a cognitive reference point in the domain of pride insofar as a number of related concepts (such as dignity, self-esteem, vanity etc.) derive from it; this form of pride is also the most prototypical example of the emotion category. 
$\mathrm{E}$ :

(16) England boss Taylor has made no secret of his admiration for the pride and passion Adams puts into his efforts for his country

(17) you either do it yourself and preserve your precious dignity

(18) Indirect Rulers ranked self-respect above all the other blessings they could bestow, wealth, health, and the conveniences of modern life paling by comparison

(19) She valued her self-respect too highly to accept dross when she knew she must seek for gold

(20) ...they also bring corresponding rewards in the way of job satisfaction and self-esteem

S:

(21) Naravno, Koštunica i Đinđić nisu, niti će ikada razumeti da srpski nacionalni ponos, čast i dostojanstvo vrede mnogo više od američkih dolara

'Koštunica and Đinđić never understood, nor is it likely that they ever will, that Serbian national pride, honour and dignity are a great deal more valuable than US dollars'

(22) I jedne i druge krasi junaštvo, ponos i veliko srce

'Gallantry, pride and a big heart adorn them'

(23) Majkl Korleone nema osobine koje su krasile njegovog oca Vita, dostojanstvo, uzvišenost

'Michael Corleone is not possessed of the qualities that adorned his father Vito, dignity, excellence'

(24) Ceo svet se divio moralu, hrabrosti i ponosu građana 'The whole world admired the citizens' morality, courage and pride' 
(25) Šta Vam je najvrednije u životu? Karakter, obraz i dostojanstvo 'What is your most precious thing in life?' Character, 'cheek' ${ }^{5}$ and dignity'

(26) [stvaraoci] koji talentom, ponosom i individualnom snagom služe kulturi svog naroda

creators serve culture pride-INST.SG

'creators who serve their people's culture with talent, pride and personal strength'

(27) Preziru nas i braća i došljaci, a mi se branimo ponosom i mržnjom.

we defend ourselves pride-INST.SG

'Our brothers and incomers despise us, but we defend ourselves with pride and hatred'

(28) Samo takvim samopoštovanjem privolećeš i druge da te poštuju you will make others respect you self-respect-INST.SG

'Only with that kind of self-respect will you make others respect you'

The choice of lexemes such as to admire, admiration and diviti se (ponosu) 'to admire pride', nekoga krasi ponos ('pride adorns somebody') points to the existence of a more specific-level metaphor PRIDE/SELF-RESPECT IS AN ORNAMENT in both languages, whereas the examples in which the Serbian nouns denoting pride and self-respect are used in the instrumental case suggest that pride and self-respect can additionally be conceptualized as AN INSTRUMENT in Serbian.

5 The Serbian lexeme obraz 'cheek' is figuratively used to represent one's honour, pride and honesty, as defined by the Dictionary of the Serbian Language (RSJ, 2007). Therefore, a person who has 'cheek' is honourable and reputable, while being without it or having 'a thick cheek' points to one's lack of dignity and sense of shame (RSJ). The dictionary definitions thus highlight the connection between the concepts of pride, dignity and honour on the one hand, and moral integrity, on the other, i.e. that pride, dignity and honour frequently derive from having strong moral principles. Similarly, the link between pride/dignity and honour is also highlighted in the English dictionaries. For example, the Oxford English Dictionary (OED) lists 'the state or quality of being worthy of honour or respect' as one of the sense descriptions of the lexeme dignity, while honour is given as one of the synonyms of the lexeme pride. (For a more detailed analysis of the sense descriptions of dignity, honour, dostojanstvo 'dignity' and čast 'honour' in the authoritative English and Serbian dictionaries see Broćić 2018a: 162-168). 
While in examples (26) and (28) the conceptualization of pride/ self-respect as an instrument is realized via case inflection alone, or, more specifically, the instrumental case, whose most basic meaning is that of a physical instrument (see Stevanović 1989; Antonić 2005; Imamović 2013), in the example such as braniti se ponosom 'to defend oneself with pride' (27), PRIDE-INSTRUMENT is further specified as A WEAPON Owing to the synergy of the meaning of the verb braniti se 'to defend oneself' and the noun denoting pride in the instrumental case. In this case, the metaphor PRIDE IS A WEAPON, as well as imparting a positive evaluation to pride, has an additional meaning focus $\square$ it highlights that pride has a vital role to play in combating negative emotions.

Even though the implied presupposition of the metaphorical structuring of pride and dignity as a prized possession is that the experiencer is eager to take possession of, and consequently retain pride/dignity-desirable object, there is an important group of examples (particularly prominent in the Serbian sample) that evoke the image of an individual who is willing to discard or sell the precious possession. The element of social disapproval is strongly attached to such an act, yielding the conceptual mapping PRIDE IS A PRECIOUS POSSESSION WHICH MUST NOT BE DISCARDED AND TREATED LIKE A COMMODITY:

$\mathrm{E}$ :

(29) She said: 'They traded in our political self-respect for representation on a committee which doesn't mean a thing to anyone

(30) That was how many of them got into the peep shows, selling off their self-respect in order to finance their habit.

S:

(31) Tom prilikom, general Lazarević je istakao da zlikovci NATO alijanse, ono što nisu postigli u oružanoj agresiji, pokušavaju sada da učine na podmukao način, angažujući one koji bi da za šaku dolara prodaju slobodu, otadžbinu, poreklo, svoj ponos i dostojanstvo.

'On that occasion, General Lazarević pointed out that NATO evildoers were trying to achieve their own ends......by employing 
those who were ready to sell their freedom, homeland, origins, as well as their pride and dignity for a handful of US dollars'

(32) Građani koji su za sitne pare prodali svoj ponos

'The citizens who sold their pride for a song/trifling sum'

(33) moji igrači nisu od početka shvatili da će ovoga puta prokockati svoj ponos i samopoštovanje

'my players at first didn't realise that this time they would gamble away their pride and self-respect'

(34) Kakav bi to bio čovek koji bi se odrekao svog dostojanstva? Kakav bi to bio narod koji bi odbacio vlastito dostojanstvo?

'What kind of man would give up his dignity? What kind of a nation would throw away its own dignity?

(35) narod izdajnicima nikada neće dati poverenje niti svoje svetinje, otadžbinu, slobodu i dostojanstvo.

'The people will never give their trust, nor their sacred objects, homeland, freedom and dignity to traitors'

(36) Poslanici SPS-a su isticali da je osnovna karakteristika DOSovske vlasti vladanje uredbama, te da je ,,politička samovolja jača od prava i zakona i da smo Hagu prodali naše dostojanstvo i objavili kraj SRJ".

'SPS (The Socialist Party of Serbia) MPs emphasized that...we had sold our dignity to the Hague (Tribunal)"

(37) Neće nas pokolebati u odbrani otadžbine ni unutrašnje destruktivne snage, koje rade za račun našeg neprijatelja.. vrlo jeftino prodaju, ne samo svoje dostojanstvo, nego i svoju zemlju.

'in a struggle to defend our homeland we will not be discouraged by the internal destructive forces which collaborate with the enemy and sell very cheaply not only their dignity, but also their country'

(38) Gdenamje ponos i dostojanstvo? Želimo li mi da sačuvamo integritet i identitet ili da.....prepustimo drugima ovo što imamo?

'Where is our pride and dignity? Do we really want to keep our integrity and identity or else... give others what we have?' 
(39) Sem što smo, po cenu svog obraza i samopoštovanja, spasavali obraz i jedinstvo EU

'except that we were saving the honour (lit. cheek) and unity of the EU at the expense of our own 'cheek'and self-respect'

(40) Ovo je sramna deklaracija, koja je potrebna da bi Srbija još više snizila svoju cenu samopoštovanja na putu u EU.

'This is a shameful declaration, and it is necessary so as to ensure that Serbia lowers the price of its self-respect on its journey to the EU'

Given the strong association between the concepts of pride and dignity on the one hand, and moral rectitude and integrity on the other, as evidenced in the above examples and dictionary definitions of pride, dignity, ponos and dostojanstvo, it is no surprise that the 'throwing away the precious possession' element of the scenario is transposed onto 'disregard for one's moral codes'. Consequently, 'gambling away or selling one's pride or dignity (to the enemy)' frequently presupposes putting selfish interests and private agendas ahead of the common good, hence the prominence of the element of social denouncement that is built into the metaphor.

On the other hand, a closer look at the Serbian examples, which predominantly come from the newspaper section of KSSJ, reveals that a negative perception of 'a morally reprehensible individual' can be reinforced through the use of more creative realizations of this metaphor - for instance, pride is not simply thrown away, but also gambled away, sold for a trifling sum, a handful of US dollars, or given to traitors and enemies of the community, as well as the choice of emphatic, emotionally loaded structures, such as rhetorical questions, exclamations, as in examples (34) and (38). Importantly, these expressions primarily apply to collective pride and dignity. It could thus be argued that metaphorical expressions and structures which carry such dramatic overtones can be consciously exploited by political leaders with a view to discrediting their opponents and arousing a wider sentiment of fear in the community by evoking images of the threat posed by the external enemy. (See relevant discussion below). 


\subsection{The elements of 'theft/loss' and 'destruction'}

As shown in the previous section, the element of the imminent danger that is closing in on the precious object is already present in the depictions of pride/dignity as A PRECIOUS OBJECT WHICH MUST NOT BE DISCARDED AND TREATED LIKE A COMMODITY. Namely, as previously shown, while the subject can, in pursuit of selfish interests and personal agendas, merely discard the precious object, this object is, more often than not, deliberately given or sold to a hostile enemy of the community. On the other hand, the wide array of the examples in which pride/dignity-object is explicitly depicted as a precious object that is being damaged or stolen from the experiencer testifies to a high level of productivity of the DAMAGE and THEFT metaphors in the conceptualization of THE (FIGURATIVE) LOSS/CESSATION OF PRIDE/SELFRESPECT in both languages:

$\mathrm{E}:$

(41) A real threat existed [...] to so much that she valued as part of her individual identity, autonomy, independence, pride, all of which would be lost...

(42) By taking away a people's culture and pride in their appearance, you literally change the way they see themselves.

(43) His words dented her pride and left her speechless.

(44) The loan was damaging to British pride.

(45) His pride in being able to cook three hot meals a day for two of us, on just one litre of meths in six days, was shattered.

(46) At least I lived as I believe, And no matter what They take from me, They can't take away my dignity.

(47) Yet in one the father did not know what was going on, and was robbed of all dignity.

(48) He's had a lifelong fight with feminists who accuse him of extreme male chauvinism and damaging their dignity. 
(49) war on drugs' as a frontal assault on a worker's dignity and entitlement to due process.

(50) Though you did make rather a big dent in my dignity.

(51) But if the experiences of work are a continual bombardment of the individual's sense of self-esteem, he can only respond aggressively in his own defence

(52) He was a thief, was Dr Pseud - he was stealing my selfrespect.

S:

(53) ...tako da se ponos, nada i dostojanstvo, zajedno sa spartanskom izdržljivošću srpskog naroda nisu gubili ni u najtežim krizama.

'pride, hope and dignity, together with the Spartan endurance of the Serbian people, were not lost, not even during the severest crises'

(54) Komentarišući to što „neki ljudi u Srbiji smatraju da su izručenjem Miloševića izgubili ponos" Đinđić je izjavio da Srbiji sada treba svež novac, kako bi se isplatile penzije, izgradila infrastruktura i obezbedilo gorivo za zimu.

'...,s,some people in Serbia think that, having extradited Milošević, they lost their pride'

(55) Srpski nacionalni ponos nije uništilo ni vekovno ropstvo pod Turcima.

'Serbian national pride was not destroyed by protracted Turkish rule'

(56) Unakazivanje osećaja nacionalnog ponosa 'the mutilation of national pride'

(57) Na sličan način treba i ubuduće rešavati sve nesporazume, podvukao je Mihajlović, kako sebe ne bismo više dovodili u situaciju da budemo gubitnici svojih teritorija, časti, ugleda, dostojanstva i suvereniteta.

'...to avoid being losers of our territories, honour, reputation, dignity and sovereignty' 
(58) Glumica živo i opipljivo predstavlja njena razarajuća osećanja, posledice...brutalno oduzetog dostojanstva.

'The actress vividly and graphically portrays her devastating feelings, the consequences of being brutally stripped of dignity'

(59) univerzum junaka ratnih i poratnih trauma i razočarenja i ukradenog dostojanstva.

'stolen dignity'

(60) Ovo je nečuveno kršenje i iranskog i međunarodnog prava, grub nasrtaj na osnovno ljudsko dostojanstvo.

'This is a flagrant violation of Iranian and international law, a vicious attack on basic human dignity'

(61) Hladnokrvne automatizovane ubice su u rušilačkom pohodu 78 dana atakovale na našu zemlju, njenu čast $i$ njeno dostojanstvo.

'Cold-blooded automated murderers spent 78 days carrying out raids against our country, its honour and dignity'

(62) U jučerašnjem saopštenju se kaže da je taj „besprimereni čin pokušaj da se naruži obraz Beograda i Srbije, a ujedno i mučki udar na kulturu i dostojanstvo srpskog naroda".

'this unsuitable act is an attempt to stain the honour (lit. cheek) of Belgrade and Serbia, as well as a savage attack on the culture and dignity of the Serbian people'

(63) Od Zapada dobijamo najteže udarce po dostojanstvu.

'Our dignity is being severely beaten by the West'

The above examples unequivocally point to the metaphorical structuring of PRIDE/SELF-RESPECT as AN OBJECT VULNERABLE TO THEFT AND DESTRUCTION, or more specifically, the conceptual mapping JEOPARDIZING ONE'S FEELING OF PRIDE/SELF-RESPECT IS STEALING/CAUSING PHYSICAL DAMAGE TO HIS/HER PRIDE-(VALUABLE) OBJECT ${ }^{6}$ in both languages, with any differences between the languages occurring at the level of more specific metaphorical images and linguistic expressions of these mappings.

6 Kövecses (2000: 30) postulates the metaphor CAUSING HARM TO A PROUD PERSON IS CAUSING PHYSICAL DAMAGE TO A STRUCTURED OBJECT in English. 
For instance, while in English 'to damage one's pride'can be specified as 'to dent one's pride' (example 43), this elaboration does not seem to exist in Serbian.

Furthermore, the negative evaluation and unpleantness/ suffering from the perspective of the experiencer seem to be especially highlighted through the wide variety and specific choice of verbal lexemes instantianting these mappings, which often carry strong emotional connotations and serve to conjure up images of violent attack and complete (wanton) destruction - i.e. damage, destroy, ruin, harm, threaten, assault, undermine, make a dent in, trample (on), bombard, erode, knock in English, and uništiti, kršiti, zbrisati, pogoditi, (po)gaziti, (grub) nasrtaj na, (mučki) udar, atak na in Serbian. The English data additionally demonstrate that self-respect can be conceptualized as a less prototypical object (for example, a textile or an object filled with air), which in turn motivates linguistic expressions such as rip, leave in shreds or puncture (one's self-respect/ dignity).

Close inspection of the Serbian examples further reveals some interesting peculiarities of the characterisation of pride/selfrespect via the DAMAGE metaphor in the Serbian corpus. Namely, it is worth noting that this metaphor is particularly productive in the conceptualisation of collective/national pride and dignity and that the majority of the examples come from the newspaper section of the Serbian corpus, often containing verbatim quotations from political speeches or interviews (for instance, (57), (61), (62)). Therefore, the observations that emerged from the analysis of the linguistic realizations of PRIDE/DIGNITY IS A PRECIOUS POSSESSION WHICH MUST NOT BE DISCARDED AND TREATED LIKE A COMMODITY seem to be equally relevant in this case: the use of dramatic and striking expressions in which national pride is not merely damaged but mutilated (example 56) may also be pragmatically motivated insofar as such expressions can be consciously employed to achieve a particular rhetorical goal - it this case, deliberately provoke or heighten fear, worry, indignation and resistance in the face of the threat posed to the prized possession. 


\subsection{The elements of 'defence/preservation' and 'recovery/returning'}

The characterisation of pride/self-respect as a precious object that can be destroyed or stolen implies the need for preservation and defence against this kind of attack, giving rise to the submapping PRIDE/SELF-RESPECT IS A PRECIOUS OBJECT WHICH HAS TO BE PRESERVED AND DEFENDED in both languages:

E:

(64) I've had plenty of relationships back in England, she went on doggedly, salvaging her pride as best she could.

(65) what the worker does to protect himself and his dignity from persecution by those who attempt to exercise control over him

(66) It is necessary to stress that elderly people facing loss do not always have to be overwhelmed by their circumstances, with very little chance of preserving their dignity or sense of self-worth.

(67) José Gabriel Tupac Amaru the Second, renegade leader of an attempt to restore the pride of the Incas, was himself executed in 1781.

(68) A little community gets back its pride.

(69) And he has given the club back its pride.

(70) It is to renew the spirit and the solidarity of the nation ... at the heart of a new mood in the nation must be a recovery of our self-confidence and our self-respect.'

(71) Kim was a passionate nationalist imbued with determination to restore self-respect to Korea and to unify the peninsula.

S:

(72) Prema njegovim rečima, ponos ovog naroda očuvan je samo zahvaljujući Miloševiću.

'According to him, it's thanks to Milošević that the nation's pride was preserved' 
(73) Podnosimo sve teškoće da bi sačuvali svoj ponos, čast, dostojanstvo i patriotizam, da bi sačuvali svoju grudu, lepu zemlju, miroljubivu i snažnu Srbiju.

'We are prepared to endure every hardship to preserve our pride, honour, dignity and patriotism, to protect our beautiful homeland, peace-loving and strong Serbia'

(74) Danas vi, mladi vojnici i mornari, prihvatate častan, izuzetno složen zadatak odbrane slobode, časti $i$ dostojanstva svakog našeg čovjeka i naše zemlje, za koju, ako zatreba, spremno dajemo i naše živote. Veliki je to ulog, ali bez časti, dostojanstva i slobode, koje su naši preci krvlju stekli, nema ni nas i nema naših životnih vrijednosti.

'Today, you, young soldiers and sailors, are taking on the honourable, and extremely complex task of defending the freedom, honour and dignity of every man and our country, for which we are ready to lay down our lives if need be'

(75) ...prećutkivanja Brozovih i Miloševićevih logora $u$ ime spasavanja srpske časti i ponosa.

'a cover-up of Tito's and Milošević's prison camps in the name of trying to salvage Serbian honour and pride'

(76) branitelj ponosa srpskog naroda i svih potlačenih ljudi, kako tvrde njegove kolege i prijatelji

'the defender of the pride of the Serbian people..., as claimed by his colleagues and friends'

(77) Na Vama je g. predsedniče [...] da li ćete [...] sačuvati obraz i dostojanstvo Crne Gore, njenu pravicu i slobodu, koja je rodila, ili ćete, što ne dao Bog, ostaviti sramni pečat na njenom obrazu, stid i poniženje.

'It is up to you, Mr. President, to protect Montenegro's honour/ cheek and dignity'

(78) U skladu sa ustavom i federalnim zakonodavstvom, kao predsednik Ruske Federacije, obavezan sam da štitim život i dostojanstvo ruskih državljana, gde god da se oni nalaze“, rekao je Medvedev, dodajući da je „gruzijska vojska u suštini izvršila akt agresije protiv ruskih mirovnjaka i civilnog stanovništva" 
'as the President of the Russian Federation, I have an obligation to protect the lives and dignity of Russian citizens, wherever they are', said Medvedev'

(79) Herojskim otporom pod rukovodstvom Slobodana Miloševića odbranjena je sloboda i dostojanstvo našeg naroda.

'Under Milošević's heroic leadership our nation's freedom and dignity were successfully defended'

(80) Slobodan Milošević je najbolje i najvernije oličenje naše Partije i borac za mir, slobodu, istinu i dostojanstvo.

'Slobodan Milošević is the best personification of our party and a champion of (lit. fighter for) peace, freedom, truth and dignity'

(81) Svim Srbima.....vraćeni su samopoštovanje, ponos i dostojanstvo.

'All Serbs have been given their self-respect, pride and dignity back'

The aforementioned observation regarding the potentially conscious use of destruction imagery to achieve a particular argumentative effect seems to be even more applicable to the linguistic realizations of the DEFENCE metaphor. Although this metaphor is realized through a relatively narrow range of stock expressions, such as očuvati, spasiti, odbraniti ponos/ dostojanstvo 'preserve, salvage, defend', the very meanings of words such as defend or defender can be said to be emotionally resonant and as such have great potential to be used in constructing political arguments. In the words of Charteris-Black (2004: 91), 'the domain of conflict highlights the personal sacrifice and physical struggle that speakers claim are necessary to achieve social goals', which accounts for linguistic realisations of this metaphor being particularly prominent in public utterances of political leaders. Namely, as evidenced in some of the Serbian examples, politicians can put themselves in the role of defender, i.e. present themselves (or be presented) as the agents of defence or recovery, possibly in an effort to drum up public support. (e.g. 72, 76, 78, 79, 80). (COLLECTIVE PRIDE/DIGNITYOBJECT IS DEFENDED BY A DISTINGUISHED INDIVIDUAL ON BEHALF OF THE COMMUNITY). Alternatively, by evoking images of 'the precious possession under threat', 
the general populace can be spurred into action and even driven to acts of violence in defence of the precious possession $(73,74) .^{7}$

What can also be observed from the Serbian examples is that in the context of attack and defence, (collective) pride and dignity frequently collocate with honour, and metonymically obraz 'cheek', indicating that all three lexemes are closely related in meaning.

As regards 'the recovery of the precious possession' element, it is obvious that the experiencer is, once again, predominantly portrayed as passive in relation to this act, as was the case with 'giving prideobject to somebody'. As evidenced above, this is especially true of the conceptualization of collective pride and dignity (e.g. 67, 71, 81).

\subsection{Summing up}

In the light of the linguistic evidence examined in this paper it can be said that the 'POSSESSION OF A PRECIOUS OBJECT SCENARIO' imparts a highly positive evaluation to the emotional experiences of pride and selfrespect in both languages, while the prominence of the elements of 'destruction/theft' and 'defence' within the scenario highlights the inherent fragility of those states and the need to constantly reaffirm them $^{8}$. The existence of the same metaphors in English and Serbian can be explained by the fact that PRIDE/SELF-RESPECT IS A PRECIOUS POSSESSION is ultimately built on the primary metaphor VALUED ASPECTS OF EXPERIENCE ARE PRECIOUS POSSESSIONS, as formulated by Grady (1999).

7 It is also noteworthy that the realizations of the DEFENCE metaphor account for as many as $22 \%$ of all the examples (metaphorical and non-metaphorical alike) containing the lexeme dostojanstvo 'dignity' in the Serbian sample.

8 The diversity of the pertinent metaphorical expressions is taken to be a major indicator of the productivity of a particular metaphor. In this respect, it is interesting to note that the corpus-based studies of the metaphorical structure of happiness in English point to an elaborate metaphorical substructure pertaining to the first element of the scenario. Namely, as shown by Stefanowitsch (2006b), the element of 'trying to acquire happiness', i.e. TRYING TO ATTAIN HAPPINESS IS SEARCHING/HUNTING FOR SOMETHING, is realized via a a wide range of lexical items: for instance, sought-after happiness, pursuit of, search/quest for happiness, $X$ chase after happiness, $X$ be in search of/pursue/seek/reach out towards/snatch at/buy happiness etc. (p. 48). Stefanowitsch further interprets his findings against a backdrop of dominant cultural values, claiming that this metaphor "forms part of a PURSUIT-OF-HAPPINESS model which is strongly entrenched in English-speaking cultures" (p. 43). We can therefore conclude that specific emotion concepts can differ with respect to the prominence of particular submappings or elements within a single, underlying scenario. 
Despite the strong conceptual parallels between the languages, the characteristic differences can be said to have arisen at the level of 'emphasis' - as is clear from the above analysis, the characterisation of pride and dignity as a precious possession, almost a sacred object, is particularly striking and productive in the structure of the collective manifestations/forms of the 'trinity of pridy, dignity and honour' in the Serbian language, which might be interpreted as an indication that these collective emotional experiences constitute core values in Serbian culture.

Before reiterating the major implications of this kind of metaphorical structuring, it is appropriate to recall the oft-quoted Lakoff and Johnson's (2003 [1980]) claim that "Metaphor may create realities for us, especially social realities. A metaphor may thus be a guide for future action. Such actions will, of course, fit the metaphor.... In this sense, metaphors can be self-fulfilling prophecies" (p. 156). In view of this, it could be argued that the construal of pride and dignity as a PRECIOUS, almost A SACRED OBJECT can further enhance the value of those emotional experiences, and consequently have a considerable bearing on the behaviour and cultural practices of people who live and act by this metaphor. On the one hand, heightened concern over the protection of one's pride/dignity/honour(-precious object) can lead one to act honourably and to the highest moral standards, but, on the other hand, and more perniciously, people who act on the basis of this metaphor can resort to violence in defence of something that they hold sacred.

Moreover, public opinion can be influenced and shaped by the manipulative use of the linguistic realisations of these mappings in political discourse. Namely, as is clear from the present findings, by exploiting the emotive potential of such metaphorical structuring, politicians can present themselves as - or be hailed as - the saviours of the sacred/precious object, thereby providing grist for personal agendas and sometimes even a politically expedient cover for warmongering. On the other hand, the use of dramatic expressions which reinforce the image of pride-treasure as being under attack can serve to drum up the patriotic spirit of the people, or simply, increase tensions and foment nationalist sentiments; they can even legitimate acts of violence perpetrated in the name of, or for the sake of trying to protect the sacred object from the enemy. 
At the same time, it is interesting to note that the abovementioned potentially negative implications of this metaphorical structuring are explicitly focused on in a few examples from the Serbian data. A case in point is the following example, in which the author appears 'to call into question' the dominant metaphorical framing:

S:

(82) Ovde sve više i sve češće, manje ili više, svi političari govore da Srbija mora sačuvati svoje dostojanstvo, da Srbija mora da vrati svoje dostojanstvo. Pa to je govorio i Milošević i kada čujem da neko na taj način govori o povratku dostojanstva, o dostojanstvu kao najvažnijoj stvari...mene obuzima nelagodnost, setim se nekih bliskih vremena.

'Here increasingly.... all politicians say that Serbia has to protect its dignity, that Serbia has to recover its dignity. Well, Milosevic himself used to say that, so when I hear that somebody refers to the recovery/returning of dignity, or describes dignity as the most important thing...I feel overwhelmed by a sense of unease, I remember the events of our recent past'

More broadly, the present analysis - or more specifically, the observation that the metaphor PRIDE/DIGNITY/HONOUR IS A PRECIOUS ОвJеСт (together with all the identified submappings constituting the scenario) creates realities, i.e. encourages people to live and act by it - can be tentatively related to the findings that have emerged from studies investigating similarities and differences in the notion of honour across cultures, as well as the role of honour (and honourrelated values) in cultural belief systems, norms and social practices (e.g. Rodriguez-Mosquera et al. 2002; Leung \& Cohen 2011; Helkama et al. 2012; Van Osch et al. 2013). Some of this research on honour has explicitly focused on the negative consequences of one's excessive preoccupation with personal honour, i.e. the study of the role of anger and aggression in defence of honour. Leung and Cohen (2011) thus highlight that in the so-called honour cultures, in which honour is a focal value, (or in cognitive linguistic terms, it can be argued that HONOUR is construed as A SACRED OBJECT), an individual whose honour has been attacked or stolen has a moral obligation to avenge him/herself. Similarly, Cohen and Nisbett (1994, as cited in Rodriguez Mosquera et al. 2002) and Van Osch et al. (2013) claim 
that men may resort to violence in defence of masculine and family honour, whereas some authors argue that the pursuit of military honour helped provoke the bloodshed of the Second World War (Robinson 2006, as cited in Helkama et al. 2012) or the wars in Bosnia-Herzegovina and Afghanistan (Royal 2008: 61-69, as cited in Helkama et al. 2012).

\section{Concluding remarks}

The corpus-based quantitative and qualitative analysis presented in this paper indicates that the 'possession of a precious object scenario' plays an essential role in the conceptualization of pride and selfrespect in both languages. The languages are found to exhibit a high degree of overlap with respect to the generic-level metaphors, with any differences between the languages predominantly occurring at the level of specific-level metaphors and specific linguistic realizations of these metaphors. The analysis has also uncovered some of the culture-specific properties of the metaphorical structuring of collective pride, dignity and honour via this scenario in the Serbian language, which may be indicative of their privileged position in the Serbian value system.

Furthermore, a comparison of the identified mappings related to pride/self-respect and the existing metaphorical conceptualization of happiness in the literature indicates that emotion concepts can vary at the level of individual elements of a single, overarching scenario. Namely, while the elements of 'destruction', 'theft/loss' and 'preservation/defence' are particularly foregrounded within the 'possession of a precious object' scenario in the structure of pride and self-respect in both languages, happiness is essentially characterized by the prominence of the element of 'trying to acquire a valuable object'.

The present analysis was performed on a large sample of corpus examples. What differentiates it from the existing corpus-based research into emotion concepts, however, is that an attempt has been made to take into account the surrounding co-text as well as the connotative and contextual meanings of metaphorical expressions ${ }^{9}$,

9 That aspect of analysis is not usually taken up in the existing corpus-based studies of emotion concepts as they, albeit drawing on large collections of naturally used examples, predominantly focus on shorter stretches of text, i.e. conceptual metaphors are formulated 
which has enabled us to connect the identified conceptual metaphors with specific cognitive models (e.g. the POSSESSED OBJECT metaphor and 'PRIDE/PONOS 2'), identify related concepts (e.g. the association between defiance and pride), to uncover metaphors featured most prominently in the structure of 'collective emotional experiences', as well as the ideological aspects of a particular metaphorical framing. This approach can thus lead to a more nuanced and accurate analysis of the complexities of the metaphorical conceptualization of emotions.

Lastly, and in relation to the last point mentioned, the findings presented in this paper have highlighted the need for a more comprehensive study of the various aspects of the metaphorical conceptualization of collective emotional experiences generally (hitherto neglected in the cognitive linguistic studies of emotion concepts). They have, more specifically, pointed to a need for further research into the conceptualization of (the trinity of) pride, dignity and honour in specific discourse settings (i.e. Serbian public and political discourse) through the prism of Critical Discourse Analysis and Critical Metaphor Analysis.

\section{References}

Antonić, I. (2005). Sintaksa i semantika padeža [The Syntax and Semantics of Cases]. In: P. Piper et al. (eds.), Sintaksa savremenoga srpskog jezika. Prosta rečenica [The Syntax of the Present-Day Serbian Language. Simple Sentence]. Beograd: Institut za srpski jezik SANU/Beogradska knjiga/Matica srpska, 119-300.

Broćić, А. (2012). О концептуализацији појмова понос, гордост, охолост и надменост у српском језику. Зборник Матище српске за филологију и тингвистику XV/2, 119-140.

Broćić, A. (2018a). „Konceptualizacija emocija samovrednovanja u engleskom i srpskom jeziku" [The Conceptualization of Self-Conscious

based on individual lexical items collocating with emotion nouns (e.g. boiling/simmering anger, anger boil/simmer in $X>$ ANGER IS A HOT FLUID IN A CONTAINER (Stefanowitsch 2006b: 19); $X$ be obedient to rage/frustration dominate $X>$ RAGE/FRUSTRATION IS A CONTROLLER/ SUPERIOR (Ogarkova \& Soriano 2014b: 100)). 
Emotions in English and Serbian]. Doctoral dissertation, Faculty of Philology, University of Belgrade.

Broćić, A. (2018b). The Conceptualization of PRIDE and SHAME in English and Serbian via the Temperature Domain. In: Z. Kašić (ed.) Primenjena lingvistika u čast Vesni Berić-Đukić - o jeziku sa raznih aspekata, Novi Sad/Beograd: Društvo za primenjenu lingvistiku Srbije, Filozofski fakultet Univerziteta u Novom Sadu, Filološki fakultet Univerziteta u Beogradu, 49-64.

Charteris-Black, J. (2004). Corpus Approaches to Critical Metaphor Analysis. Basingstoke/New York: Palgrave Macmillan.

Deignan, A. (2005). Metaphor and Corpus Linguistics. Amsterdam: John Benjamins.

Deignan, A. (2006). The Grammar of Linguistic Metaphors. In: A. Stefanowitsch and S. Gries (eds.), Corpus-based Approaches to Metaphor and Metonymy, Berlin and New York: Mouton de Gruyter, 106-122.

Deignan, A. (2008). Corpus Linguistics and Metaphor. In: R. Gibbs (ed.), The Cambridge Handbook of Metaphor and Thought, Cambridge University Press, 280-294.

Dziwirek, K. and B. Lewandowska-Tomaszczyk (2010). Complex Emotions and Grammatical Mismatches: A Contrastive Corpus-Based Study. Berlin/ New York: Mouton de Gruyter.

Goatly, A. (2007). Washing the Brain: Metaphor and Hidden Ideology. Amsterdam: John Benjamins.

Grady, J. (1997). "Foundations of Meaning: Primary Metaphors and Primary Scenes". Doctoral dissertation, University of California, Berkeley.

Grady, J. (1999). A Typology of Motivation for Conceptual Metaphor: Correlation Vs. Resemblance. In: R. W. Gibbs and G. Steen (eds.), Metaphor in Cognitive Linguistics, John Benjamins, Philadelphia, 79-100.

Helkama, K. et al. (2012). Honor as a Value in Finland, Estonia, Italy, Russia, and Switzerland. Group Processes \& Intergroup Relations, 16, 3, 279-297.

Imamović, A. (2013). Metaphor and Metonymy in Legal Texts. Jezikoslovlje, 14 (2-3), 295-306.

Klikovac, D. (2004). Metafore u mišljenju i jeziku, Beograd: XX vek.

Klikovac, D. (2006[2000]). Semantika predloga - Studija iz kognitivne lingvistike, Beograd: Filološki fakultet ( $2^{\text {nd }}$ edition). 
Kosanović, M. (2009). "Konceptualizacija emocije sreće u engleskom i srpskom jeziku". MA Thesis, Faculty of Philology, University of Belgrade.

Kosanović, M. (2016). "Pridevi koji označavaju emocije u engleskom i srpskom jeziku: kognitivnolingvistička analiza". Doctoral dissertation, Faculty of Philology, University of Belgrade.

Kövecses, Z. (1986). Metaphors of Anger, Pride, And Love: A Lexical Approach to the Structure Of Concepts. Amsterdam/Philadelphia: John Benjamins.

Kövecses, Z. (1998). Are There Any Emotion-Specific Metaphors? In: A. Athanasiadou and E. Tabakowska (eds.), Speaking of Emotions: Conceptualization and Expression, Berlin/New York: Mouton de Gruyter, 127-151.

Kövecses, Z. (2000). Metaphor and Emotion. Language, Culture, and the Body in Human Feeling. Cambridge/New York: Cambridge University Press.

Kövecses, Z. (2005). Metaphor in Culture. Universality and Variation. Cambridge: CUP.

Kövecses, Z. (2008a). The Conceptual Structure of Happiness. In: H. Tissari, A. B. Pessi and M. Salmela (eds.), Happiness: Cognition, Experience, Language, Helsinki: Helsinki Collegium for Advanced Studies, 131-143. Kövecses, Z. (2008b). Metaphor and Emotion. In: R. Gibbs (ed.), The Cambridge Handbook of Metaphor and Thought, Cambridge: Cambridge University Press, 380-396.

Kövecses, Z. (2010[2002]). Metaphor. A Practical Introduction. New York and Oxford: Oxford University Press.

Kövecses, Z. (2014). Conceptualizing emotions. A revised cognitive linguistic perspective. (15 March 2018) <https://www.researchgate.net/ profile/Zoltan_Koevecses/publication/274208283_Conceptualizing_ emotions_A_revised_cognitive_linguistic_perspective $>$.

Lakoff, G. (1987). Women, Fire, and Dangerous Things: What Categories Reveal about the Mind. Chicago: University of Chicago Press.

Lakoff, G. (1993). The Contemporary Theory of Metaphor. In: A. Ortony (ed.), Metaphor and Thought ( $2^{\text {nd }}$ edition), Cambridge: Cambridge University Press, 202-251.

Lakoff, G. and M. Johnson (2003[1980]). Metaphors We Live By. Chicago: University of Chicago Press.

Lakoff, G. and M. Johnson (1999). Philosophy in the Flesh. New York: Basic Books. 
Langacker, R. W. (1987). Foundations of Cognitive Grammar vols. 1 \& 2, Stanford, CA.: Stanford University Press.

Langacker, R. W. (1991). Foundations of Cognitive Grammar. Vol. II: Descriptive Application. Stanford CA: Stanford University Press.

Leung, A. K. Y. and D. Cohen (2011). Within- and Between-Culture Variation: Individual Differences and the Cultural Logics of Honor, Face, and Dignity Cultures. Journal of Personality and Social Psychology, 100(3), 507-526.

Ogarkova, A. and C. Soriano (2014a). Emotion and the Body: A Corpus-Based Investigation of Metaphorical Containers of Anger Across Languages. International Journal of Cognitive Linguistics, 5(2), 147-179.

Ogarkova, A. and C. Soriano (2014b). Variation Within Universals: The 'Metaphorical Profile' Approach to the Study of Anger Concepts in English, Russian and Spanish. In: A. Mussolf, F. MacArthur and G. Pagani (eds.) Metaphor and Intercultural Communication, London: Bloomsbury Academic, 93-116.

Ogarkova, A. and C. Soriano (2018). Metaphorical and Literal Profiling in the Study of Emotions. Metaphor and Symbol, 33 (1), 19-35.

Rodriguez Mosquera, P.M., Manstead, A.S.R., and A.H. Fischer (2002). Honor in the Mediterranean and Northern Europe. Journal of CrossCultural Psychology, 16-36.

Semino, E. (2017). Corpus Linguistics and Metaphor. In: B. Dancygier (ed.), The Cambridge Handbook of Cognitive Linguistics, Cambridge: Cambridge University Press, 463-476.

Soriano, C. (2013). Conceptual Metaphor Theory and the Grid Paradigm in the Study of Anger. In: J. R. J. Fontaine, K. R. Scherer and C. Soriano (eds), Components of emotional meaning: A sourcebook, Oxford: Oxford University Press, 410-424.

Soriano, S. C. (2015). Emotion and Conceptual Metaphor. In: H. Flam and J. Kleres (eds.), Methods of Exploring Emotions. New York \& London: Routledge, 206-214.

Stefanowitsch, A. (2006a). Corpus-Based Approaches to Metaphor and Metonymy. In: A. Stefanowitsch and S. Gries (eds.), Corpus-based Approaches to Metaphor and Metonymy, Berlin and New York: Mouton de Gruyter, 1-16.

Stefanowitsch, A. (2006b). Words and Their Metaphors. A Corpus-Based Approach. In: A. Stefanowitsch and S. Gries (eds.), Corpus-based Approaches to Metaphor and Metonymy, Berlin and New York: Mouton de Gruyter, 63-105. 
Stevanović, M. (1989 [1 $1^{\text {st }}$ ed. 1964]). Savremeni srpskohrvatski jezik I-II, [The Present-Day Serbo-Croatian Language, Vol. I and II]. Beograd: Naučna knjiga.

Van Osch, Y. et al. (2013). A Different Kind of Honor Culture: Family Honor and Aggression in Turks. Group Processes \& Intergroup Relations 16 (3), 334-344.

\section{Sources}

BNC - British National Corpus. Available at http://corpus.byu.edu/bnc KSSJ - Korpus savremenog srpskog jezika [Corpus of the contemporary Serbian language]. Matematički fakultet, Univerzitet u Beogradu, 2013. Available at http://www.korpus.matf.bg.ac.rs.

OED - Oxford English Dictionary. Available at https:// en.oxforddictionaries.com/

RSJ - Rečnik srpskoga jezika [Dictionary of the Serbian language]. Novi Sad: Matica srpska, 2007.

Received: 14 December 2018

Accepted for publication: 28 December 2018

Андријана Броћић

ПОНОС КАО МЕТАФОРИЧКО БЛАГО: КОНЦЕПТУАЛИЗАЦИЈА ПОНОСА

И САМОПОШТОВАҢА У ЕНГЛЕСКОМ И СРПСКОМ ЈЕЗИКУ ПУТЕМ „СЦЕНАРИЈА ПОСЕДОВАЮА ДРАГОЦЕНОСТИ”

\section{Сажетак}

У овом раду испитује се концептуализација групе емоција које се односе на позитивно самовредновање - pride, self-respect, self-esteem и dignity у енглеском и понос, самопоштовағе и достојанство у српском језику - путем метафоричког сценарија који смо назвали „сценарио поседовања драгоцености”. Анализа је спроведена на теоријској подлози когнитивне лингвистике и у методолошким оквирима анализе примера из општих корпуса. Резултати указују на висок степен продуктивности датог метафоричког сценарија у структури поноса и самопоштовања у оба језика, као 
и на изразитост елемената 'уништавања', 'отимања/губитка' и 'очувања/одбране' драгоцености у структури испитиваних појмова. Осим тога, анализа показује да је метафоричко уоквиравање тројства поноса, достојанства и части као драгоцености изразито наглашено у српском корпусу, што упућује на њихов вредносни статус у српској култури, али и на манипулативне аспекте оваквог метафоричког уоквиравања у јавном дискурсу. Резултати стога упућују на потребу за даљим испитивањем колективног поноса, достојанства и части и у окриљу критичке анализе дискурса.

Кључне речи: понос, самопоштовање, достојанство, појмовна метафора, драгоценост, енглески, српски 